Галина Непомняща

Глухівський національний педагогічний університету імені Олександра Довженка

ORCID ID 0000-0002-5148-2105

DOI 10.24139/2312-5993/2020.09/225-237

\title{
ПІДГОТОВКА МАЙБУТНЬОГО ВЧИТЕЛЯ ДО ОПРАЦЮВАННЯ ОКРЕМИХ ВИДІВ ПРОСТИХ ЗАДАЧ У СУЧАСНІЙ ПОЧАТКОВІЙ ШКОЛІ
}

У статті проаналізовано сучасні підходи до підготовки майбутнього вчителя початкової школи до професійної діяльності, зокрема до викладання математичних дисциплін. Розглянуто підготовку майбутніх учителів до опрацювання окремих видів простих задач під час навчання учнів математики в сучасній початковій школі. Обгрунтовано значення математичних задач для учнів початкових класів. зазначено класифрікатор простих задач, окреслено конкретні види простих задач. Досліджено методичний аспект вивчення зазначених видів задач. Розглянуто конкретні приклади задач і окреслена робота з ними.

Ключові слова: підготовка майбутнього вчителя, початкова школа, окремі види простих задач.

Постановка проблеми. Формування професійної компетентності майбутнього вчителя початкових класів відбувається у процесі навчання в закладі вищої освіти і спрямовується на набуття майбутнім фахівцем знань, умінь, позитивних ставлень, досвіду професійної діяльності й поведінкових моделей особистості у професійному середовищі.

3 позиції компетентнісного підходу рівень фахової підготовки майбутніх учителів визначається здатністю вирішувати проблеми та професійні завдання різної складності на підставі наявних знань та досвіду. Сучасній школі потрібен компетентний учитель початкових класів, спроможний ефективно діяти, розв'язувати стандартні та проблемні завдання, що виникають в освітньому процесі.

Повноцінне навчання математики учнів початкових класів неможливе без володіння вчителем методикою навчання математики, знання методичних підходів до вивчення певних тем курсу.

У Державному стандарті початкової освіти зазначено, що метою освітньої математичної галузі $€$ формування математичної та інших ключових компетентностей; розвиток мислення, здатності розпізнавати й моделювати процеси та ситуації з повсякденного життя, які можна розв'язувати із застосуванням математичних методів, а також здатності робити усвідомлений вибір (Державний стандарт початкової освіти, 2018).

Відповідно до Державного стандарту початкової освіти розроблено типову освітню програму, у якій визначено очікувані результати для 
кожного класу, коротко вказано відповідний зміст предмета чи інтегрованого курсу.

Математична галузь спрямована на розкриття ролі математики в пізнанні явищ і закономірностей навколишнього світу; формувати в дітей основи математичних знань та способів дій, досвід їх використання для розв'язування навчальних і практичних задач; реалізовувати потенціал галузі для закладання здатності міркувати логічно, оцінювати коректність і достатність даних для розв'язування навчальних та практичних задач; для розвитку математичного мовлення, що необхідне для опису математичних фактів, відношень і закономірностей (Типові освітні програми для закладів загальної середньої освіти: 1-2класи, 2018). Реалізація означених завдань здійснюється за такими змістовими лініями: «Числа, дії з числами. Величини», «Геометричні фігури», «Вирази, рівності, нерівності», «Математичні задачі і дослідження», «Робота з даними». Тому актуальним $\epsilon$ питання підготовки майбутніх учителів до вивчення методичного аспекту реалізації основних змістових ліній.

У нашому дослідженні ми зупинимося на питанні підготовки майбутніх учителів початкової школи до опрацювання простих математичних задач, зокрема окремих їх видів.

Аналіз актуальних досліджень. Вагомий внесок у розробку методологічних засад проблеми навчання розв'язувати математичні задачі зроблено М. Бантовою, М. Богдановичем, Ю. Колягіним, О. Корчевською, М. Моро, О. Онопрієнко, А. Пишкало, Г. Саранцевим, С. Скворцовою та ін.

У методичній літературі висвітлюються різні аспекти формування в учнів початкової школи умінь розв'язувати прості задачі, але недостатньо приділено уваги проблемі підготовки майбутніх учителів до опрацювання окремих видів простих задач, зокрема поєднанню теоретичного й методичного їх аспектів.

Мета статті. Метою нашої статті $€$ висвітлення особливостей підготовки майбутніх учителів початкових класів до опрацювання окремих видів простих задач у початковому курсі математики.

У процесі написання статті використані такі методи дослідження: критичний аналіз літератури, порівняння, узагальнення практичних досліджень, систематизація.

Виклад основного матеріалу. Метою змістової лінії «Математичні задачі і дослідження» $€$ формування в учнів здатності розпізнавати практичні проблеми, які можна розв'язати із застосуванням математичних методів. Математичні задачі, зокрема сюжетні, $€$ важливим засобом 
ілюстрації й конкретизації навчального матеріалу; розвитку пізнавальних процесів і оволодіння прийомами розумових дій (аналізу, синтезу, порівняння, узагальнення, класифікації, конкретизації); $є$ засобом формування дії моделювання; виховання особистісних якостей, естетичних почуттів; розвитку вміння будувати судження, робити висновки; формування в учнів мотивації їхньої навчальної діяльності, інтересу та здатності до цієї діяльності (Типові освітні програми для закладів загальної середньої освіти: 1 -2 класи, 2018). Сюжетні задачі, особливо практично зорієнтовані, забезпечують зв'язок математики з реальним життям дитини. В учнів початкової школи необхідно формувати поняття про задачу, її структурні компоненти, про сутність процесу розв'язування.

Одним із основних завдань математичної галузі $\epsilon$ набуття учнями загального вміння розв'язувати прості сюжетні задачі. Тому майбутніх учителів доцільно ознайомити з послідовністю роботи над математичною задачею. У процесі такої роботи учні можуть досліджувати вплив складників задачі на їі розв'язання за різних варіацій умов: добирати умову до запитання, змінювати умову відповідно до запитання, змінювати запитання відповідно до виразу тощо. Доцільно розглядати задачі 3 реалістичним сюжетом. Водночас, навчальні дослідження можуть поширюватися не лише на сюжетні задачі, а й на інші види завдань. Доречно проаналізувати математичні завдання на визначення змін в умові задачі та їх вплив на її розв'язання. Корисними є завдання, які мають не один, а кілька правильних розв'язків, кілька способів розв'язування. Навчальні дослідження доцільно включати до завдань через спонукання до дослідницьких дій: з'ясуй, встанови, визнач, досліди тощо.

Робота над математичними задачами i 3 навчальними дослідженнями $€$ важливим ресурсом для реалізації міжпредметних зв'язків та інтеграції зі змістом інших освітніх галузей (Початкова освіта, 2018, с. 13-14).

Всі задачі в початковому курсі математики поділяються на прості і складені. Прості задачі - це такі, для розв'язання яких потрібно виконати одну арифметичну дію.

Прості задачі ми можемо розділити на такі 4 групи: задачі, які розкривають конкретний зміст кожної арифметичної дії; задачі, які розкривають зв'язки між компонентами і результатами арифметичних дій (задачі на знаходження невідомого компонента); задачі на різницеве порівняння; задачі на кратне порівняння. 
I група задач - це задачі, які розкривають конкретний зміст кожної арифметичної дії - включає такі види простих: задачі на знаходження суми, задачі на знаходження остачі, задачі на знаходження добутку як суми однакових доданків, задачі на ділення на рівні частини, задачі на ділення на вміщення.

II група задач - це задачі, які розкривають зв'язки між компонентами і результатами арифметичних дій (задачі на знаходження невідомого компонента) - включає такі види простих: задачі на знаходження невідомого доданка, задачі на знаходження невідомого зменшуваного, задачі на знаходження невідомого від'ємника, задачі на знаходження невідомого множника, діленого і дільника.

III група задач - це задачі на різницеве порівняння - включає такі види простих: задачі на збільшення та зменшення на кілька одиниць, задачі на збільшення та зменшення на кілька одиниць у непрямій формі; задачі на різницеве порівняння.

IV група задач - це задачі на кратне порівняння - включає такі види простих: задачі на збільшення та зменшення в кілька разів, задачі на збільшення та зменшення в кілька разів у непрямій формі; задачі на кратне порівняння.

Існують окремі види простих задач, які не належать до жодної із зазначених вище груп. Це прості задачі на знаходження швидкості, часу, відстані; на знаходження площі; на знаходження частини від числа і числа за його частиною; що містять знаходження дробу від числа, числа за значенням його дробу; на обчислення тривалості, дати початку події, її кінця.

У нашому дослідженні ми розглянемо методику опрацювання зазначених вище видів задач у процесі вивчення математичної галузі в сучасній початковій школі.

Одними з перших розглядаються задачі на обчислення тривалості, дати початку події, її кінця. Такі задачі на час містять три компоненти: дата початку події, тривалість події і дата закінчення події. Вони розпочинають вивчатися з 2 класу.

Під час проведення лекційних і практичних занять з методики навчання освітньої галузі «Математика» доцільно розглянути методику опрацювання таких задач.

Наприклад, задача: «Уроки в школі починаються о 8 год 30 хв. Тривалість уроків 45 хв, перерв - 10 хв. В учнів 2 класу було 4 уроки. О котрій годині закінчуються заняття?»

До задачі можна додати короткий запис із ключовими словами. 
Педагогічні науки: теорія, історія, інноваційні технології, 2020, № 9 (103)

\begin{tabular}{|l|l|l|}
\hline Час початку події & Тривалість події & Час закінчення події \\
\hline & & \\
\hline
\end{tabular}

Під час розгляду таких задач необхідно із студентами проаналізувати послідовність роботи з такою задачею. Скласти бесіду для її аналізу. Після аналізу задачі складається план розв'язання задачі і відповідно записується розв'язок задачі та відповідь.

Розв'язавши пряму задачу, доцільно скласти до неї 2 обернені і проаналізувати їх.

У подальшому розв'язання таких задач ускладняється. Наприклад, задача: «Учні виїхали на екскурсію 12 жовтня о 8 год ранку, а повернулися 13 жовтня о 20 год. Скільки часу тривала екскурсія?»

Спочатку звертаємо увагу студентів на аналіз задачі, з'ясовуємо, що в ній відомо і про що потрібно дізнатися. Короткий запис складаємо за допомогою таблиці.

\begin{tabular}{|l|l|l|}
\hline Дата початку події & Тривалість події & Дата закінчення події \\
\hline 12 жовтня 8 год & $?$ & 13 жовтня о 20 год \\
\hline
\end{tabular}

Під час вивчення таких задач з'ясовуємо правила, які $є$ необхідними для роботи з таким видом задач:

- щоб знайти час закінчення події, треба до часу початку події додати тривалість події;

- щоб знайти тривалість події, треба від часу закінчення події відняти час початку події;

- щоб знайти час початку події, треба від часу закінчення події відняти тривалість події.

Методика опрацювання має бути розглянута на лекційних заняттях і закріплена практично.

Наступним видом $є$ задачі на знаходження частини від числа і числа за його частиною.

Безпосередньою підготовкою до введення задач цього виду $\epsilon$ засвоєння правила знаходження частини від числа, яке вводиться на основі уявлень учнів про частини та знань про отримання частин.

Під час розгляду методики опрацювання таких задач звертаємо увагу студентів на практичну роботу, яку необхідно провести. Учням пропонується накреслити відрізок, наприклад, довжиною 16 см, показати четверту частину цього відрізка і пояснити, що це: четверта частина - це одна з чотирьох рівних частин цілого, том,у щоб отримати чверть, треба довжину цілого відрізка 16 см поділити на 4 рівні частини, показати одну таку частину і назвати ії довжину. Потім учитель радить виміряти довжину однієї четвертої частини відрізка і повідомляє, що ми знайшли величину 
однієї чверті від $16 \mathrm{~cm}$. Учні з'ясовують, якою арифметичною дією знаходять чверть від 16 см, і формулюють правило знаходження частини від числа. Потім розглядається правило знаходження частини від числа, що застосовується під час розв'язання завдань, і лише після його засвоєння учням пропонуються сюжетні задачі на знаходження частини від числа i показується схематичний короткий запис.

Ознайомлення із задачами на знаходження частини від числа можна провести на прикладі такої задачі: «Учні посадили 12 дерев. 1/4 всіх дерев - каштани. Скільки каштанів посадили учні?»

-Прочитайте умову задачі.

-Прочитайте запитання задачі.

- Складемо короткий запис задачі.

запис на дошиі і в зошитах

Задача

Посадили - 12 д.

Каштани - ?, 1/4всіх дерев.

- Повторимо задачу за коротким записом.

Переходимо до практичних дій з паличками.

- Викладіть на парті стільки паличок, скільки дерев посадили учні. Скільки паличок ви виклали на парті? (12).

- Чому 12? (Тому що учні посадили 12 дерев).

- Яку частину всіх дерев становлять каштани? (1/4 всіх дерев становили каштани).

- Покажіть одну четверту всіх паличок. Відсуньте їх вправо.

- Скільки паличок відсунули вправо? (3).

- Що означає кожна паличка, розміщена на парті справа? (Каштан).

- Скільки каштанів посадили діти? (3).

- Якою дією можна дізнатися про число каштанів? (Дією ділення).

- Чому? (Тому що потрібно кількість всіх дерев поділити на 4 рівні частини і взяти одну таку частину).

- Який приклад складемо? Про що дізнаємося?

- Чому треба 12 поділити на 4? (Щоб знайти 1/4 всіх дерев, треба число всіх дерев поділити на 4 рівні частини).

- Запишемо розв'язання задачі.

Запис на дошиі і в зошитах

Розв'язання

$12: 4=3\left(\kappa_{.}\right)$

Відповідь: 3 каштани посадили учні. 
- Прочитайте відповідь задачі.

3 метою ознайомлення із задачею на знаходження числа за його частиною можна розглянути таку задачу: «Тарас розв'язав 10 задач. Це 1/6 всіх задач, які мав розв'язати Тарас. Скільки задач мав розв'язати Тарас?»

-Скільки задач розв'язав Тарас?

-Яка це частина всіх задач?

-Яке запитання задачі?

- Складемо короткий запис задачі.

Запис на дошиі і в зошитах

Задача

BCbOzO - ?

Розв'язав - 10, 1/6 всіх задач.

-Як нам дізнатися, скільки задач мав розв'язати Тарас? (Щоб дізнатися, скільки задач мав розв'язати Тарас, потрібно 30 помножити на 6).

—Яку дію треба виконати, щоб розв'язати задачу? (Дію множення).

-Який приклад складемо? Про що дізнаємося?

-Запишемо розв'язання задачі.

Запис на дошиі і в зошитах

Розв'язання

$$
10 \cdot 6=60(3)
$$

Відповідь: 60 задач мав розв'язати Tарас.

-Прочитайте відповідь задачі.

Також ознайомлення із задачею на знаходження числа за його частиною можна ввести як обернену до прямої задачі на знаходження частини від числа.

У подальшому варто подавати задачі обох видів парами, можна подавати взаємообернені задачі.

1. У коробці було 6 олівців, з них 1/3 - прості. Скільки простих олівців було в коробці?

2. У коробці було 2 простих олівці, що становить $1 / 3$ частину від усіх олівців коробки. Скільки олівців у коробці?

Звертаємо увагу майбутніх учителів, що під час роботи з такими видами задач учні з'ясовують, що вони знаходять: ціле чи його частину; більшою чи меншою за дане число має бути відповідь. Якщо більшою, то задачу розв'язуємо множенням, якщо меншою - діленням.

Наступним видом окремих видів є задачі на знаходження швидкості, часу, відстані. Вони вивчаються в 4 класі і вводяться послідовно. Спочатку розглядається задача на знаходження швидкості, потім часу, потім 
відстані. Підготовча робота до таких задач проводиться під час екскурсій у процесі спостереження за рухом транспорту, пішоходів. Учні спостерігають за рухом різних тіл. Визначаючи, що одне тіло рухається швидше, а інше - повільніше. Також спостерігають в умовах класу рух двох тіл відносно одне одного, коли двоє учнів починають рухатися одночасно в одному напрямі, заздалегідь зазначається час руху або відстань, яку повинні подолати учні.

Спостерігаючи за рухом кількох тіл, учні помічають, що за один і той самий час два тіла можуть пройти різну відстань; одну й ту саму відстань два тіла можуть подолати за різний час.

Ознайомлення з поняттям «швидкість» відбувається на основі задачі: «За 3 години автобус проїхав 180 км, проїжджаючи щогодини однакову кількість кілометрів. Скільки кілометрів проїжджав автобус за 1 год?»

Необхідно ознайомити студентів зі схематичною ілюстрацією умови задачі і проаналізувати послідовність роботи з такою задачею. Також зазначаємо, що в результаті розгляду задачі вводиться правило знаходження швидкості і формула знаходження швидкості. Аналогічно на двох наступних уроках вводяться задачі на знаходження часу й відстані.

У подальшій роботі з такими задачами короткий запис складається за допомогою таблиці.

\begin{tabular}{|l|l|l|}
\hline Швидкість & Час & Відстань \\
\hline & & \\
\hline
\end{tabular}

Вибір дії визначають на основі правила. Формулювання правила доцільно вивісити на дошці. 3 метою закріплення можна виконати кілька завдань на знаходження часу за відомими відстанню і швидкістю та навпаки.

3 метою закріплення розуміння учнями поняття «швидкість» доцільно розв'язати такі задачі:

1) За 9 годин машина проїхала 747 км. Скільки кілометрів вона проїжджала за 1 годину? Яка швидкість автомобіля?

2) Бігун пробіг 300 м за 50 с. Скільки метрів він долав за 1 секунду? 3 якою швидкістю біг бігун?

Під час розв'язання таких задач корисно звернути увагу на те, що вони містять не два запитання, а одне, яке сформульовано по-різному.

Наступним видом задач $є$ задачі на знаходження дробу від числа і знаходження числа за значенням його дробу.

Необхідно проаналізувати зі студентами особливості підготовчої роботи до задач даного виду. Вона охоплює повторення задач на знаходження частини від числа і практичну роботу учнів із роздатковим матеріалом. Під час проведення підготовчої роботи учні мають 
усвідомити, що коли ціле поділити на рівні частини, то кожна частина буде менша від цілого; чим на більшу кількість поділено ціле, тим меншою буде кожна його частина.

Ознайомлення учнів можна провести на прикладі такої задачі: «у книжці 180 сторінок. Учень прочитав 2/6 усіх сторінок книжки. Скільки сторінок прочитав учень?»

Прочитавши зміст задачі, вчитель переходить до ії аналізу.

- Про що розповідається в задачі?

- Скільки сторінок у книжці?

-Скільки сторінок прочитав учень?

- Як ви розумієте вираз «учень прочитав 2/ 6 усіх сторінок книжки»?

- Яке запитання задачі?

- Складемо короткий запис задачі.

запис на дошиі і у зошитах

Задача

Всього - $180 \mathrm{~cm}$.

Прочитав - ?, 2/6 усіх сторінок.

- Як нам дізнатися, скільки сторінок книжки прочитав учень? (Щоб дізнатися, скільки сторінок книжки прочитав учень, потрібно кількість усіх сторінок книжки поділити на 6 рівних частин і взяти 2 такі частини).

- Який приклад складемо? Про що дізнаємося?

- Запишемо розв'язання задачі.

Запис на дошиі і в зошитах

Розв'язання

$180: 6$ • $2=60$ (cm.) - прочитав учень.

Відповідь: учень прочитав 60 сторінок.

-Яка відповідь задачі?

3 метою закріплення пропонуємо розв'язати учням кілька аналогічних задач і розглянути матеріал підручника з математики, що відповідає темі.

Також у 4 класі учні вивчають задачі на знаходження числа за значенням його дробу. Підручники з математики для 4 класу не містять таких видів задач. Тому вчитель самостійно має дібрати й пояснити учням особливості розв'язання таких задач.

Задачі на знаходження числа за значенням його дробу можна ввести як обернені до задач на знаходження дробу від числа або на прикладі певної задачі. Наприклад, задача «У книжці 180 сторінок. Це 2/6 усіх сторінок книжки. Скільки сторінок у книжці?». Методика роботи таких задач аналогічна до задач на знаходження дробу від числа, але основою 
обґрунтування вибору дії є правило: «Щоб знайти ціле за величиною його дробу, треба величину дробу розділити на чисельник, а потім помножити на знаменник».

Задачі на знаходження площі прямокутника, згідно з програмою, вивчають у 4 класі, коли вводиться поняття площі.

Розглядаємо з майбутніми вчителями початкової школи, що ознайомлення 3 поняттям площі і навчання обчислювати площу прямокутника водночас $\epsilon$ підготовчими для задач цього виду. Учні засвоюють правило: «Щоб обчислити площу прямокутника, треба визначити його довжину й ширину та знайти добуток цих чисел». У підручнику подані різні прямокутники, площу яких потрібно обчислити. Діти вимірюють довжину і ширину кожного прямокутника та обчислюють площу за правилом. Пізніше за відомою площею прямокутника та однією з його сторін учні вчаться обчислювати другу сторону прямокутника.

Наступним кроком мають бути розглянуті прості задачі на знаходження площі та однієї зі сторін прямокутника. На жаль, простих задач у сучасних підручниках з математики для 4 класу практично немає, а $\epsilon$ лише складені. Але перш ніж опрацьовувати складені задачі, доцільно ввести кілька простих задач на знаходження площі як сюжетних, так і абстрактних. Частину цих задач можна розв'язати під час усних обчислень. Наприклад, можна розглянути такі задачі:

1) Сад має форму прямокутника. Довжина саду 30 м, а його ширина 10 м. Чому дорівнює площа саду?

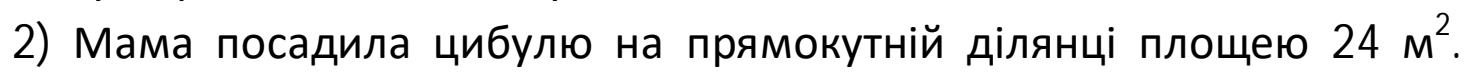
Ширина ділянки 4 м. Яка довжина ділянки?

Під час опрацювання таких задач визначають, що відомо, а що $\epsilon$ шуканою величиною. Вибір дії аргументують на основі правила на знаходження площі.

Задачі на знаходження площі розв'язують як прямі, так і складають обернені, що забезпечує підготовку до розв'язання складених задач зі знаходженням площі.

Висновки та перспективи подальших наукових розвідок. Отже, підготовка майбутнього вчителя до формування в учнів початкових класів умінь розв'язувати окремі види простих задач $\epsilon$ необхідною умовою оволодіння ними предметною математичною компетентністю. Це формує в учнів здатність застосовувати набуті компетентності в потрібний момент у конкретних життєвих ситуаціях, шукати шлях розв'язання пізнавальних та практичних завдань, сприяти формуванню творчої 
винахідливості й дослідницької діяльності. Отже, підготовка майбутніх вчителів має бути спрямована на вдосконалення їхніх методикоматематичних знань і вмінь щодо проблеми опрацювання окремих видів простих задач у сучасній початковій школі.

Подальшої розробки потребує дослідження інтегрованого підходу до опрацювання простих задач у процесі підготовки вчителя початкових класів до професійної діяльності.

\section{ЛІТЕРАТУРА}

Державний стандарт початкової освіти [Затверджено постановою Кабінету Міністрів України від 21 лютого 2018 р. № 87] (2018). Retrieved from: http://nus.org.ua/ wpcontent/uploads/2018/03/5a8de25e1504c877583228.do.

(State standard of primary education [Approved by the Cabinet of Ministers of Ukraine Decree No. 87 of February 21, 2018] (2018). Retrieved from: http:// nus.org.ua/ w pcontent/uploads/2018/03/5a8de25e1504c877583228.do.

Корчевська, О. П. (2008). Навчаємо математики. Методика роботи над задачами. Тернопіль: Мандрівець (Korchevska, O. P. (2008). We teach mathematics. M ethods of working on tasks. Ternopil: Mandrivets).

Нова українська школа: порадник для вчителя (2017). Київ: ТОВ «Видавничий дім «Плеяди» (New Ukrainian school: a guide for teachers (2017). Kyiv: Pleiades Publishing House).

Початкова освіта. (2018). Методичні рекомендації щодо використання в освітньому процесі типової освітньої програми для 1 класів закладів загальної середньої освіти; типова освітня програма для закладів загальної середньої освіти (колективу авторів під керівництвом О. Я. Савченко); методичні коментарі провідних науковців Інституту педагогіки НАПН України щодо впровадження ідей Нової української школи в початковій освіті. К.: УОВЦ «Оріон», (сс. 13-14) (Primary education. (2018). M ethodological recommendations on using the standard educational program for the 1-st form of general secondary education institutions in the educational process; a typical educational program for general secondary education institutions (edited by 0. Ya. Savchenko); methodological comments of leading scientists of the Institute of Pedagogy of the National Academy of Pedagogical Sciences of Ukraine on the implementation of the ideas of the New Ukrainian School in primary education. Kyiv: «Orion», (pp. 13-14)).

Скворцова, С. О. (2011). Методика навчання розв'язування сюжетних задач у початковій школі: Навчально-методичний посібник для студентів за спеціальністю 6.010100 «Початкове навчання». Частина І. Методика формування в молодших школярів загального уміння розв'язувати сюжетні задачі. Одеса: ООО «Абрикос-Компани» (Skvortsova, S. О. (2011). Methods of teaching to solve the plot problems in primary school: a textbook for students in specialty 6.010100 "Primary Education". Part I. M ethods of forming primary school pupils' a general ability to solve plot problems. Odessa: "Apricot Company").

Типові освітні програми для закл. загальної середньої освіти: 1 -2 класи. (2018). К.: ТД «OСВІТА-ЦЕНТР+» (General educational programs for general secondary education establishments: 1-2 forms (2018). Kyiv: Trading House "Educational Center +") 


\section{PEЗЮME}

Непомнящая Галина. Подготовка будущего учителя к изучению отдельных видов простых задач в современной начальной школе.

В статье проанализированы современные подходы к подготовке будущего учителя начальной школы к профессиональной деятельности, в частности $к$ преподаванию математики. Рассмотрена подготовка будущих учителей к изучению отдельных видов простых задач при обучении учащихся математике в современной школе. Обосновано значение математических задач для учащихся начальных классов. Указан классификатор простых задач, определены конкретные виды простых задач. Исследован методический аспект изучения указанных видов задач. Рассмотрены конкретные примеры задач и очерчена работа с ними.

Ключевые слова: подготовка будущего учителя, начальная школа, отдельные виды простых задач.

\section{SUM M ARY}

Nepomnyashcha Halyna. Preparation of a future teacher to learning some kinds of simple problems in the modern primary school.

Forming the professional competence of a future primary school teacher takes place in the process of studying in a higher education institution and is aimed at acquiring knowledge, skills, positive attitudes, professional experience and personality behaviour in the professional environment.

According to the competence approach, the level of future teachers' professional training is determined by the ability to solve the problems and professional tasks of different complexity on the basis of existing knowledge and experience. A modern school needs a competent primary school teacher who is able to act effectively, to solve standard and problematic tasks that arise in the educational process.

Full-fledged teaching of mathematics to primary school pupils is impossible without the teacher's mastery of teaching methods on mathematics in primary school, knowledge of methodological approaches to teaching certain topics of the course.

A significant contribution to the development of the methodological foundations of the issue of teaching to solve mathematical problems was made by $M$. Bantova, M. Bohdanovych, Yu. Koliahin, O. Korchevska, M. Moro, O. Onopriienko, A. Pyshkalo, H. Sarantsev, S. Skvortsova and others.

The methodological literature highlights various aspects of forming primary school pupils' ability to solve simple problems. But the issue of preparing future primary school teachers to training certain types of simple problems is not given enough attention, in particular the combination of theoretical and methodological aspects.

The purpose of the article is to highlight the peculiarities of preparing future primary school teachers to train certain types of simple problems during the initial course of mathematics.

In the process of writing the article such research methods were used: critical analysis of the literature, comparison, generalization of practical research; systematization.

Condusions and prospects for further scientific research. Thus, preparation of a future teacher for forming primary school pupils' ability to solve certain types of simple problems is the necessary condition for their mastering mathematical competence. It forms pupils' ability to apply the acquired competences at the certain time in specific life situations, to find a way to solve cognitive and practical tasks, to promote forming the creative ingenuity and research. Thus, future teachers training should be aimed at improving their 
methodological and mathematical knowledge and skills according to the issue of training certain types of simple problems in modern primary school.

The integrated approaches to teaching of simple problems in the process of preparing primary school teachers for professional activities is required further development.

Key words future teacher training, primary school, some types of simple problems.

\title{
Удк 378.147
}

\author{
Олена Паламарчук \\ Харківський національний технічний \\ університету сільського господарства \\ імені Петра Василенка \\ ORCID ID 0000-0003-4547-4587 \\ DOI 10.24139/2312-5993/2020.09/237-248
}

\section{ПРОБЛЕМИ ОРГАНІЗАЦІї ДИСТАНЦІЙНОЇ ТА ЗМІШАНОЇ ОСВІТИ В УНІВЕРСИТЕТАХ УКРАÏHИ}

У статті аналізуються форми організації дистанційного та змішаного навчання в закладах вищої освіти України. Розглядається спільне та відмінне в поняттах «дистанційне» $i$ «змішане». Автором визначено чинники, які впливають на здійснення ефективної моделі навчання, виокремлено позитивні та негативні сторони дистанційного та змішаного навчання. У статті віднесено до негативних сторін організації дистанційного та змішаного навчання відсутність високого рівня педагогічної майстерності та досвіду роботи з новітніми технологіями у викладачів, необхідність різних курсів підвищення їх кваліфікачії, нових форм здійснення комунікації зі студентами. Автором розглянуто особливості впровадження дистанційного та змішаного навчання в освітній процес, поєднання різних видів діяльності, форм контролю й оцінки знань студентів.

Ключові слова: дистанційне та змішане навчання, ефективна модель навчання, новітні технології, форми навчання, види діяльності, контроль знань.

Постановка проблеми. Вирішення нових завдань, поставлених перед системою освіти України процесами державотворення, кардинальними змінами в суспільно-політичному житті людей, вимагає вироблення адекватної організаційної структури системи освіти, яка б забезпечувала перехід до принципу «освіта впродовж усього життя» через добре відому в усьому світі систему організації дистанційного навчання. Дистанційне навчання (distance learning, distance education) - це така форма організації освітнього процесу, основою якої $\epsilon$ самостійна робота людини, яка навчається. Розвиток дистанційної освіти в Україні розпочався значно пізніше, ніж у країнах Західної Європи, наприкінці 90-х років, у зв'язку з недостатнім рівнем інформатизації українського суспільства, через брак комп'ютерної техніки в закладах освіти України та відсутність спеціалізованих методик дистанційного і змішаного навчання. 